\title{
The Imagined Space of Academic Life: Leacock, Callaghan, and English-Canadian Campus Fiction in Canada, 1914-1948
}

\author{
There is always someone around the campus who likes to talk about life there. \\ (Callaghan 1948, 3)
}

\author{
E. Lisa Panayotidis, Paul Stortz \\ University of Calgary
}

\section{ABSTRACT}

Since the earliest establishment of universities in Canada, campuses have been the backdrop against which students, professors, administrators, and staff negotiated an important part of their daily lives. Through interpretive and contextual historical understandings, members of the public and the university community visually and discursively constructed the campus but they were in turn also intensely shaped by it. This article examines two seminal fictional accounts that depict the historical Canadian university campus: chapter 3 of Stephen Leacock's Arcadian Adventures with the Idle Rich (1914) and Morley Callaghan's The Varsity Story (1948). As part of a broader genre of campus fiction, these works focus on the symbolic cultural meanings and experiences that were ascribed to the natural and built environment of the university. These books were narrated through fictional actors and imbue the geography and space of the campus and one's lived experiences with moral significance, a tapestry on which historical academic and intellectual worlds unfolded.

RÉSUMÉ

Depuis la création des universités au Canada, les campus ont fait l'objet de négociations par les étudiants, les professeurs, les administrateurs et le personnel administratif pour l'amélioration d'une partie importante de leurs conditions de vie au quotidien. À travers le temps et grâce à des ententes et à des échanges mutuels, la population en général et la communauté universitaire ont d'une manière régulière ou sporadique façonné les campus, mais en retour en ont été fortement influencées. Cet article analyse deux créations littéraires renommées qui ont décrit l'histoire des campus universitaires canadiens. La première se trouve dans le chapitre trois de l'œuvre de Stephen Leacock, Arcadian Adventures with the Idle Rich (1914) et l'autre provient du livre de Marley Callaghan intitulé The Varsity Story (1948). Ces textes font partie d'un genre plus vaste qui englobe les fictions universitaires et mettent l'accent sur les significations culturelles symboliques et les expériences attribuées à l'environnement naturel et construit de l'université. Des personnages fictifs relatent ces histoires dans le décor géographique et spatial des campus où ils vivent des expériences ayant une implication morale. Un tableau dans lequel se déploient les univers académiques et intellectuels. 
In the first half of the twentieth century, the Canadian urban campus was a physical space culturally forged in the public and private imagination. Comparable to a small town in its offering of housing, meals, social and recreational life, and education, the campus - Latin for "field" or "an expanse surrounded by woods or higher ground" - was a world unto its own. This idyllic academic village was often conceived as an exclusive space that nurtured youth during their post-secondary education by providing a maternal home away from home. The picturesque and bucolic university campus in Canada was adoringly portrayed by university denizens and the public for its lush and expansive lawns and its rus in urbe (country in the city), collegiate neo-Gothic and Romanesque architecture, marble stairways, lofty turrets, and frightening but endearing gargoyles. ${ }^{2}$ Campus buildings served as metaphors for the university's historical pedigree and modern "arrival," where natural and intellectual spaces converged. To cultivate the "mind" often required cultivating the "lawn."3

Early official historians and chroniclers of the university as well as numerous novelists romanticized the campus to uncover its raison d'etre. The beautification of the campus was linked to the university's crucial educative purpose and activity. Even the notion of "college spirit" was expressed in particular spatial arrangements. As geographer Edward Relph suggests, "place and sense of place ... are inextricably bound up with all the hopes, frustrations and confusions of life." "Homogenous notions of space, or spatiality, gave way to the campus as a negotiated place defined by one's lived experiences and academic relations and encounters. Shared meanings were enacted within shifting temporal and physical contexts and environments. Space became invested with meaning, allowing agents to become "implaced" by subjectively intertwining their identities and bodily experiences of the self to the campus. Historical agents did "not merely react and respond to the environment ... [they] actively represent[ed] and construe[d] it." 5

The campus in Canada was popularly represented and reproduced through a variety of media such as university yearbooks, student and city newspapers, alumni and popular magazines, memoirs, autobiographies, postcards, decorative and topographical maps, paintings and illustrations, films, plays, and poetry. More than any other medium, however, literature - specifically campus fiction - spawned vibrant discourses about the space and place of the university campus and cultural understandings about the intersecting functions of intellectualism, academic learning, teaching, student life, professors, and the institution. In text and image, the campus was often cast as an elite enclave and, to some readers, an impenetrable intellectual grove and pastoral refuge. Populated by eccentric characters, the campus was rife for satirical exposé that fuelled "collective fantasies of academe." 6

Writers have enhanced our understanding of the historical university in Canada as a mythical place of larger-than-life people with idiosyncratic motivations and comportment, and eccentric behaviour. In this paper, we discuss two seminal fictional accounts of the historical English Canadian university: writer, humorist, and McGill University professor Stephen Leacock's 1914 Arcadian Adventures with the Idle Rich; and author and University of Toronto alumnus Morley Callaghan's 1948 The Varsity Story. These "fictional-factual" depictions ${ }^{7}$ of Canadian universities are positioned within their 
author's own frameworks. By using Leacock and the understudied work of Callaghan as instructive case studies, we advance critical interpretations of the interrelationships among campus space, academic identities, lived experiences, and intellectual cultures. These two examples of Canadian campus fiction allow for an efficacious analysis of our historical understandings of the imagined academic life and space of the Canadian university as an object of scrutiny and popular and literary deconstruction.

Some other examples of campus fiction in Canada during our period of study do not focus on the campus space to the extent that Leacock and Callaghan do. While we could have included novels such as Constance Beresford-Howe, Of This Day's Journey (1949), and Régis Messac's Smith Conundrum: Roman d'une université américaine (1942), ${ }^{8}$ for the purposes of this paper, we focus on Leacock and Callaghan because of the popular and lasting effects of their campus fiction to audiences on and off campus. For Leacock (1869-1944) and Callaghan (1903-1990), both internationally known at the time they wrote the works discussed here, we argue that the space of the campus was a site of one's intellectual and moral-making. Leacock and Callaghan envisioned the campus as a place that was impacted by a nostalgic rural past and an urban future. In fictionalizing campus space, they were observers to the "tribal rites of their colleagues from an insider's perspective," as argued recently by Elaine Showalter when describing professors who write about their own universities and campus intrigues. ${ }^{9}$

Although Plutoria is portrayed as an American university, Leacock's satirical institution likely represented an amalgam of McGill University ${ }^{10}$ the University of Toronto, where he completed his undergraduate work; and the University of Chicago, of which he was also an alumnus. A particularly poignant chapter in Leacock's famous work and Callaghan's novella of the University of Toronto offer indispensable historical representations of cultural and academic spatial entrenchment and transformation of two of Canada's older English-Canadian universities. Furthermore, both Leacock and Callaghan conceptualized the university and its "sense of place" within the broader urban surroundings in which the university was situated. They forged a dialogic, nostalgic, and modern relation between the campus and the city, past and present.

The symbolic cultural meanings and experiences that historical agents - in this case the writers - ascribe to the space and place of the university demonstrate the complexity of focusing on the campus as a single literary phenomenon. Our study of the "fictional-factual" campus also draws on the field of literary geography that is part of the broader field of cultural geography, and how writers conveyed "feelings, viewpoints, values, attitudes, and meanings associated with landscape and place."11 Works from literary geography have informed how we understand both fictional and actual places not simply as topographic and geographic but as social and cultural markers that are shaped by moral geographies and normative understandings. In the end, we are interested in how historical agents understood, interpreted, and imaginatively represented diverse socio-academic communities and what Lavender Harris calls the "cultural significance of place." ${ }^{12}$ The city and the campus held this relational engagement. The notion of space within and without the university was of particular 
concern to modernists such as Callaghan and anti-modernists such as Leacock. As historian Thomas Bender has noted, universities are likely to both be "in and not of the city and in and of the city." 13

Histories of higher education have largely restricted discussion of university spaces to the chronological development of built structures. Campus landscapes, buildings, and educational environments are often under-theorized by ignoring the complex social and cultural forces on and off campus that act upon them. Our study is informed by an interdisciplinary literature that focuses on the historical campus, the concept of place-making, and the symbolism of spatiality and place that links to identity and embodiment. These works argue that the body, space, and place mediated subjective interactions among historical agents and the material worlds of the campus. They illuminate the historical geographic imagination. The place of the campus is problematized by its external and internal borders and regions, for example in the uneven conceptual divisions among the sciences, social sciences, and humanities that changed over time. These divisions differed for each agent, and were constantly contested and remade. Accordingly, a study of negotiated and fluid socio-cultural worlds of universities becomes more intimate. ${ }^{14}$

This problematized perspective also introduces new investigations into concepts in the history of universities in Canada such as intellectual and academic "initiation," "crowds," “individuality," "achievement," "success," "belonging," the "public and private," "community," and "hierarchy." We explore how particular public representations of the Canadian university unfolded in satirical or literary form, especially when framed through notions of space and place. Popular ruminations about the university - how people came to comprehend an institution so powerful in society, yet, for a large part of the twentieth century, so unreachable and distant to some - is integral to this study. The university was shaped by the collective imagination, and garnered a great deal of popular interest in the activities, mechanizations, lives, and inhabitants of such a unique educational and intellectual space.

Placing Canadian campus fiction in a larger international context, twentiethcentury works ${ }^{15}$ have offered potent images of professors, students, ${ }^{16}$ and university intellectual cultures. Character-driven literary snapshots, both satirical and serious, have provided biting images of the lives of the professoriate and the intricacies of institutional politics, power, elitism, and marginalization particularly in regard to race, gender, and class. Occasionally, they have been set within a murder mystery. ${ }^{17}$ Post-war novels such as C. P. Snow's The Masters (1951), Mary McCarthy's Groves of Academe (1952), and Kinsley Amis's Lucky Jim (1954) ${ }^{18}$ are said to mark the emergence of contemporary American and British campus fiction. Without mention of campus novels in Canada, contemporary writer David Lodge highlights Vladimir Nabokov's novel Pnin (1955) as one of the first campus fiction novels. Rossen has noted that the tone of many of these novels is such that the authors "have raided the University for fictional material and gutted it with crude malice." 19

Campus novels had multiple audiences and intents. Showalter observes that " $[\mathrm{i}] \mathrm{n}$ the days before there were handbooks, self-help guides, or advice columns for graduate students and junior faculty, there were academic novels teaching us how a proper 
professor should speak, behave, dress, think and write, love, succeed and fail." ${ }^{20}$ Portrayals in campus novels provided readers with stereotypical and clichéd interpretations of life on campus. "These novels are social documents, but they are also fiction: private fantasies writ large across cultural norms, expectations and novels." ${ }^{21}$ Mortimer R. Proctor noted the rise of the British university novel with John Gibson Lockhart's 1823 Reginald Dalton. By 1898, George Saintbury's article in Macmillan's Magazine, "Novels of University Life," represented important literary criticism of a contextual and evolving genre. Instead of literary trends or "novelistic movements," university fiction in England was more heavily influenced by actual academic conditions at Oxford and Cambridge, prompting what Proctor calls the "cult of Oxford" and the genre of the "Oxford novel." 22

\section{Through the Iron Gates of Leacock's Plutoria University}

Leacock was "the English-speaking world's best known humorist from about 1910 until his death." 23 He was widely published in Canada, the United States, and England. His work was serialized in Good Housekeeping, American Magazine, and College Humor, among other periodicals. ${ }^{24}$ As a follow-up to his popular 1912 book, Sunshine Sketches of a Little Town, which takes place in the small fictional town of Mariposa, Arcadian Adventures offers a scornful narrative about the evils and seemingly baseless values and greed of the modern city. Chapter 3 serves as a scathing attack on university administrators and modernist perceptions of the university as representing social and intellectual advancement while continually crassly seeking philanthropic endowments.

In Arcadian Adventures, Leacock caustically assailed the elites of a fictional American city for their class privilege, wasteful extravagances, and corruption. A political economist who studied under sociologist and economist Thorstein Veblen at the University of Chicago, Leacock researched the notion of conspicuous and nonproductive consumption by the leisure classes. ${ }^{25}$ In Arcadian Adventures, Leacock pointed to the hypocrisy, self-interest, and deception of the business, academic, and religious sectors of society, and argued that the onset of technology and urbanization was counterproductive to positive cultural change. It was a dark social and moral vision of early twentieth-century urbanism that provided an incisive critique of class relations and politics based on wealth. An anti-modernist who bemoaned the loss of the small-town world in which he grew up, Leacock was aghast at the flagrant materialism of the industrial age and the class of elites poised to exploit it. As James Doyle suggests, Leacock "ultimately rejected socialistic solutions to economic evils"; ${ }^{26}$ he turned to satiric ridicule to voice his cynicism about the changing institutions and conditions in a time of economic and social change.

While Plutoria University was set in an American city, the various characters in the book are likely patterned after Montreal society. As one of McGill's most famous professors, Leacock's views were honed at the McGill Faculty Club and Montreal's Pen and Pencil Club. He had a penchant for "mak[ing] fun of McGill's obsession with expansion." ${ }^{27}$ Narrated as a series of vignettes, the chapters in Arcadian Adventures are 
threaded together by the recurring figures who exercise authority and self-indulgence as members of the cultural pinnacle of the aptly-named "Mausoleum Club." The cast of male characters that populates the club include bankers, lawyers, business leaders, clergy, and university administrators and professors. In the chapter titled "The Arrested Philanthropy of Mr. Tomlinson," the idiosyncratic President Boomer of Plutoria University is introduced as a Latin-dropping, larger-than-life figure bent on cajoling unwitting benefactors on behalf of the university. The ritualistic performance of the "campus tour" is conducted. President Boomer is accompanied by his colleague, Dr. Boyster. Notably, Boyster is a professor of Greek, indicating a possible cynical connection to "Arcadia," which was a classical Greek vision of an idyllic and morally uplifting pastoral utopia, antithetical in character to Plutoria. Boomer's and Boyster's names are likely meant to connote late nineteenth- and early twentiethcentury civic boosterism fueled by the business interests that had helped shape urban and industrial expansion and the growth of cities and universities. Accordingly, for President Boomer, the campus tour is crucial since "no rich man could look at the campus] without wanting to give it money." 28

On the campus tour, President Boomer and Professor Boyster lead a prospective benefactor, Tomlinson, who was described as a "wizard of finance" and farmer, supposedly turned millionaire. Tomlinson is prompted by Boomer to imagine himself as a member of Plutoria, an elite institution akin to a private club. Beside a row of elm trees at the majestic iron gates marking the entrance of the university, Boomer proudly asserts: "This, Mr. Tomlinson, is our campus," to which Tomlinson naively inquires: "For camping?" "Not exactly," answers the president, "though it would, of course suit for that Nibil humanum alienum eh?"29 Surveying the "smooth grass" of the campus and perhaps not entirely persuaded by the president's response, revealing his agricultural background, Tomlinson asks: "[y]ou don't ... raise anything on it?"30

The campus landscape and the sense of place is constituted throughout Leacock's work. As they walk around the campus, the president recounts to Tomlinson the relationship among intellectual life, the professoriate, and teaching and learning, and their links to the built environment of the campus and the city beyond its borders. The campus landscape serves as a cultural image that symbolizes a dialogue among education, aesthetics, ethics, identity, and the past. The campus gates, trees, expansive lawns, and meandering paths are iconographic elements that shaped how the campus was culturally envisaged. They draw from the ancient emblem of the Plato's academia amidst the sanctity of the Arcadian olive groves. ${ }^{31}$ Through Tomlinson's philanthropy, however, President Boomer sees an opportunity to demolish the old classical remnants of Plutoria University, beginning with the old Faculty of Arts building, Concordia College, and transform the university's brick and mortar infrastructure and space to match the modern cityscape that borders the campus. "This, I am ashamed to say,' said Dr. Boomer, as they passed the imitation Greek portico of the old Concordia College building, 'is our original home, the fons et origo of our studies, our faculty of arts ...' It was indeed a dilapidated building." Boomer is forced to admit, however, that due to its long history as a focal point on campus "there was a certain majesty about it, too ..." Nonetheless ... "Dr. Boomer's one idea was to 
knock the building down and to build on its site a real facultas ... with elevators in it." He was clearly more partial to the mechanical sciences buildings, because they

[were] exceptionally fine, standing fifteen stories high and comparing favourably with the best departmental stores or factories in the City. Indeed, after nightfall, when they are all lighted up for the evening technical classes and when their testing machinery is in full swing and there are students going in and out in overall suits, people have often mistaken the university, or this newer part of it, for a factory. A foreign visitor once said that the students looked like plumbers, and President Boomer was so proud of it that he put the phrase into his next Commencement address. ${ }^{32}$

While "[Leacock's own] ... attitudes toward universities [were] too ambivalent for him to remain content with being primarily a professor," in many of his short stories and novels he often used the university and its cast of characters as sardonic pawns. ${ }^{33}$ He viscerally related academic cultures and identities to the space of the campus, animating the campus and making its denizens more visible for appraisal and criticism. His protagonists and supporting characters provoke rumination on socio-intellectual lives active within the physical space of the campus. It also allowed him to narrate the "old college" as a serene and traditional academic life of study and embedded human relations. "[T]he older part of the university stands so quietly and modestly ... so hidden by the leaves ... that no one could mistake it for a factory. This ... was the whole university, and had stood there since colonial days ... It had been filled with generations of presidents and professors of the older type with long white beards and rusty black clothes ..."34 After completing Arcadian Adventures, Leacock intended to write a series of short stories entitled "Annals of Concordia College" that dealt exclusively with professors. While they were not realized, in 1925 Leacock wrote the more serious "The Transit of Venus," which incorporated many of the ideas originally planned for his lampooning of the professoriate. ${ }^{35}$

Turning the readers' attention more firmly to the members of the campus, the tour continues with President Boomer pointing out the various idiosyncrasies of professors who, for example, can handle first-year but not second-year classes and those who were "all right with the second but broke down in the third"; some professors who taught their own subject well, but were "perfectly impossible outside of it"; and yet others who knew the subject but could not lecture. As they were walking, Boomer pointed out one professor: "That's Professor Withers," said the president in a sympathetic voice as one of the shivering figures went past; "poor Withers," and he sighed. "What's wrong with him?" said [Tomlinson]; "is he sick?" "No, not sick," said the president ... "merely inefficient ..." Even Professor Boyster himself, with whom Boomer and Tomlinson were walking, did not go without some creative narrative deconstruction. Boyster "had known the president for forty-five years, ever since he was a fat little boy with spectacles in a classical academy, stuffing himself on irregular Greek verbs as readily as if on oysters." ${ }^{36}$ While Leacock often lampooned professors and administrators for their idiosyncratic affectations, Leacock himself was often 
described as a "campus character" — dishevelled, his clothes mismatched, and subject to absent-mindedness. ${ }^{37}$ Boomer seems to be commenting on a university that was seemingly archaic, its intransigent eccentricity stuck in time. Professors can be both oblivious and culpable, however, in President Boomer's ruinous agendas for the university. Plutoria campus is populated with calculating administrators and inept and addled professors preoccupied with the minutiae of futile academic bickering - remarked by the dean of the faculty of arts that "the motion that they had before them amounted practically to a revolution" — over such matters as, for example, the replacement of lead pencils in examination rooms. ${ }^{38}$

Leacock also did not necessarily laud the nature and behaviour of the students on a co-educational campus. His 1938 essay, "On the Need for a Quiet College," describes his ideal college, exemplifying his often vociferous objections to female university students at McGill: "College girls are better companions, better wives (as your own or someone else's) than any others. It's the women who have made our college life the bright happy thing it is - too bright, too happy. But men can't study [his emphasis] when women are around. And it's not only the students. If I let the women in, they'd get round some of my dusty old professors and marry them - and good-buy [sic] to Machiavelli, and higher thought." ${ }^{39}$

These sentiments are brazenly expressed in Arcadian Adventures, in which male and female students are contrasted by their sex and educational attainment. "[F]emale students with winged-victory hats" are the anonymous yet fashionable and distracting backdrop of campus. "And, of course, [the university] had long since admitted women, and there were now beautiful creatures with Cleo de Merode hair studying astronomy at oaken desks and looking up at the teacher with eyes like comets." 40 They were rarely written as aspiring or ambitious. As with the professors and administrators, the male student embodied the university and off-campus society, both of which were so badly in need of critique. One young male demonstrator working with senior professor of geology "Gildas" — receives a fuller character treatment than almost any other woman student. The demonstrator "knew nothing, or practically nothing, of geology because he came of one of the richest and best families in town ... [He] was a smart young man, dressed in the latest fashion, with brown boots and crosswise tie, and knew more about money and business and the stock exchange in five minutes than Professor Gildas in his whole existence." ${ }^{11}$ Here, Leacock satirizes the elite university as being out of touch with the economic and practical considerations of the day, and unfortunately that the knowledge used to succeed in life lay in an education removed from the classical university mandates and curricula.

Arcadian Adventures of the Idle Rich promoted the old nostalgic university that was antithetical to the concerns and vicissitudes of the off-campus world. Two essays by Leacock from the 1930s stand out for their specific commentary on the university campus and its environs. The essays written during this period exhibit a "more conversational style, and an increasing personal frankness ... In one way or another Leacock wrote about himself and his life." ${ }^{2}$ In his 1936 essay, Leacock reveals an affection for the professoriate and the sad decline of a university world changing beyond recognition that is unlike his previous biting characterization. "During all 
my thirty-five years of College teaching I always felt that there was no profession in the world for which I would have exchanged for my own." Bemoaning the "hurrying world," he reflected on the "medieval scriptorium, with a stained-glass window under the light of which a scholar copied upon vellum a volume of Polybious ... [and] an Elizabethan rectory where a pious Hooker penning his Ecclesiastical Polity looked out over the clipped lawns and the immemorial trees." ${ }^{33}$ In "On the Need for a Quiet College" (1938), Leacock romantically connects his vision of academic culture to the campus itself:

If somebody would give me about two dozen very old elm trees and about fifty acres of wooded ground and lawn — not too near anyway and too far from anywhere - I think I could set up a college that would put all the big universities of today in the shade ... I would need a few buildings ... stone, if possible — and a belfry and clock.

Returning to one his favourite topics, Leacock continued that "most of all, I should need a set of professors. I would need only a dozen of them - but they'd have to be real ones ... ${ }^{44}$

In Arcadian Adventures, in the end, Tomlinson is destroyed by the university itself but not before the university grants him an honorary degree: "A university must keep its word," after all. ${ }^{45}$ Leacock offers a cautionary tale about the excesses of greed and the allure of industrial and business partnerships that have overrun the university's mission of critical humanistic studies. Gildas discovers that the gold deposits on Tomlinson's land were, unbeknownst to Tomlinson, nothing more than pyrite or fool's gold, thus serving as an allegory of Plutoria's own ill-advised embrace of the materialistic age. ${ }^{46}$

\section{The Varsity Story}

Morley Callaghan was a well-known and prodigious Canadian novelist, short-story writer, playwright, and later a television and radio personality. ${ }^{47}$ Between 1928 and 1988, he wrote on Canadian topics, oft-times in small avant-garde modernist Paris and New York journals as well as much more widely-circulated North American magazines such as Saturday Night, Scribner's Magazine, and Atlantic Monthly. Callaghan was regarded as helping to "smash ... a time-worn tradition" of the "difficult" American market. ${ }^{48}$ In a 1928 interview with journalist Margaret Lawrence, Callaghan remarked: "I have a literary faith in Canada. It is a great and awful country. Like the whole of the continent. Its literature and its art should be like the country. Tempestuous and dark. Think of the rocks and the pines. But we try to be like the English. We should do as the Dublin group did. Get back to our native sources ... This is the new world. Why should we write for an old one?” 49

Although written in 1948, The Varsity Story is set in 1924, a time not unfamiliar to Callaghan, who graduated from the University of Toronto in 1925. The Varsity Story tells of the fictional, recently-appointed warden of Hart House, New 
Zealander Arthur Tyndall. ${ }^{50} \mathrm{He}$ is disheartened by what he observes as the University of Toronto's lack of "academic character." For Tyndall in the second year of his appointment, the university seems at first glance merely a "facts factory ... [a] place [with] ... no atmosphere, no colour ... [and] no flair." ${ }^{51}$ The university spaces and places impact Tyndall's experiences and his ongoing critique of the uninspired campus culture. Writing to his fiancée back home, Tyndall puzzles at how a "provincial" university such as Toronto was a disconnected jumble of myopic sectarian and denominational arts colleges. Referring to a condition of multiple personalities, Tyndall suggested that the university could be compared to "a sick personality called George."

Pious George goes to St. Michael's [College], Laughing Cynical George goes to University College, Complacent Comfortable George goes to Trinity, Evangelical George goes to Victoria [College], and Dumb Practical George goes to the School of Practical Science; and not all the psychiatrists in the Medical School can ever put George together so that he can come out into the sunlight as one real personality. ${ }^{52}$

To Tyndall, who spent three years at Oxford, the University of Toronto was merely a poor copy, a stilted and disingenuous doppelganger, of the proud English university. In comparison to Oxford, Toronto was morally and historically anemic and stodgy. While the university was still beholden to imperial traditions and British values, it was seemingly lacking in any ambition to forge its own mission. Tyndall argued that Canadians found comfort in their appeal to British academic traditions as opposed to generating an original culture of institutional and intellectual "vigour" and "grandeur." At one point, he laments the city's and university's "dismal lack of passion." 53 Here, Callaghan was critiquing the "old world" attachments of Canadian elite institutions as pedantic and misguided. ${ }^{54}$

The plot of The Varsity Story follows Tyndall's inquiry into the very essence and passion of the university. As Tyndall wanders through the campus and attends the occasional event such as a varsity football game, his encounters with students, professors, and staff assemble images of life on campus. In one incident, walking towards the library, Tyndall happened upon the "six-foot-two, slim shouldered and longlegged" Professor $\mathrm{H}-[$ sic $]$ of the Philosophy Department who "of course always had an indulgent air." The professor playfully grilled Tyndall on how to distinguish "a man from the University of Toronto ... from a Queen's man, a McGill man ... a Yale man, or a Michigan State man." Tyndall remarks that the Toronto man "isn't intellectually adventurous ... [he] likes to fit into the accepted pattern." Similar to his initial impression of the university, Tyndall continues that "I can tell you what he isn't but I couldn't tell you what he is." ${ }^{5}$

With each person Tyndall meets, he slowly unravels the puzzle that has plagued him about the university. He starts to appreciate the university for its own merits and, contrary to his initial interpretation, uncovers a uniquely vibrant and rich social culture. Tyndall's radical transformation — indeed a revelation - from base critic to booster of the university is forged through his on-campus walks and conversations 
with such characters as Tom Lane, a student who challenges him to see the campus as a living organism of dialogic interrelations between the people and the environment. Callaghan endows the campus with an unassailably expressive resonance- - a blending of fact and fiction in its use of actual people and highly eccentric personalities. The "factual fictional" link between journalism and fiction writing is intrinsic to Callaghan's work, making The Varsity Story Callaghan's "most personal and revealing book." Of the two central characters in the book-Hart House Warden Tyndall and the student Lane - Lane "shares with his creator a similar background, interest in sports, and eclectic program of academic studies. His interests and personal convictions are given as representative of an intellectually independent liberal arts student at the time, if not representative of Callaghan himself." ${ }^{\prime 6}$

In the final chapter of The Varsity Story, at the outbreak of the Second World War, Tyndall is preparing to enlist as an educational officer and leave campus. Notably, while throughout much of the book Tyndall threatens to finally leave the university, he is still there sixteen years later. While earlier in the book Tyndall sneers that Toronto is "a violent climate for scholars...sweltering sun in July and stinging cold in the winter," ${ }^{57}$ walking in the December snow, he is now overcome with "each little landmark [as] a poignant reminder of the past." He reminisces about his experiences at the university: "Suddenly [Tyndall] couldn't bear to make the little turn at the place where the path leads down the steps into the valley, back of the library; he couldn't bear to get a sudden glimpse of the campus and the dark snow-shadowed University College and Hart House his home." 58

At an emotional farewell dinner in his honour at Hart House, Tyndall cathartically confesses his original concerns about the university. "I'm ashamed to reveal this, but ... after I had been here about a year ... I realized I had a rather low opinion of the University ... I was a first-class hypocrite." "Why did you stay on?" someone asked. Tyndall replied: "I got interested that's all. I started off on a wild-goose chase and I think I got to love the chase, for the end of the chase was always over the hills, but the hills were always beyond the horizon." ${ }^{59}$ Tyndall described his time at the university as an educational exercise through a geographic metaphor that was in the end transformative of him and his love for the campus culture and its intellectually and emotionally replenishing surroundings.

Callaghan's understanding of the artist's and writer's place in Canadian culture and her/his position as an intellectual and cultural critic is clearly evident in the book's narrative. Many literary critics have marginalized The Varsity Story as "highly subjective," "curious," "rambling and nostalgic," and inconsequential given its topic. ${ }^{60}$ Despite its clear and accessible prose and often engaging anecdotes, some critics have noted that the book does not reflect the quality of writing expressed in Callaghan's other books. Nonetheless, The Varsity Story is best seen not as one of Callaghan's lesser works, but as an effective and entertaining "masked autobiography" and a unique and useful memoir of socio-academic life on a Canadian campus and the university's position in a national and international context.

In initial reviews, literary critics curiously noted the originality of the book. William Arthur Deacon, literary editor of the Globe and Mail, wrote a lengthy review 
of the book under the provocative title: "Is the University of Toronto a Machine or Living Entity?" Deacon surmised that The Varsity Story is "neither a history of the University of Toronto nor a novel in any accepted sense [but] ... one of those peculiarly Canadian hybrids that defy classification ... It is a ... book that fails to prove anything by the rules of logic: yet it suggests terrific complexities and points vaguely toward certain truths of the utmost significance to the functions of this monster institution in our social fabric." ${ }^{61}$ Likewise, in his 1948 review for the Canadian Forum (of which he was editor at the time), University of Toronto professor Northrop Frye noted that The Varsity Story "was a sort of intellectual guidebook to the University of Toronto, cast into the form of fiction." Reflecting on Callaghan's blended use of fictional and actual university people, Frye adds that "the boundary between fact and fiction is difficult to find ... perhaps more difficult for the insider than anyone else." 62

By October 1948, a "rumor was running strong ... that a good many of the faculty in the different colleges were taking a dim view of the book. Some of them even went so far as to say it was not a novel but a controversial pamphlet in a new and human interest format." ${ }^{63}$ Notably, and as Frye points out, The Varsity Story held (and holds) a certain cachet as an "insider's story" of the university. It is a story that evokes nostalgic forms of remembrance as a way to memorialize one's time at varsity that was a constant feature of university and alumni experience. Such narratives of what some alumni considered to be the time of their lives illustrated how time and distance amplified roseate feelings of finding oneself again at the university. One reviewer of The Varsity Story drew on this sense of "tragic remembrance" noting that

... there is not a Varsity man between the ages of 18 and 80, who on reading the "Varsity Story" will not be flushed with a nostalgia as powerful as any he has ever felt in his life. And he will be baffled by two immediate considerations; how has Callaghan done it; and why has this nostalgia never been evoked before? ... It is the first time, on reading The Varsity Story, that I have wished, thirty years too late, that I could have my Varsity days over again. ${ }^{64}$

As the Varsity remarked, “'The Varsity Story' will be of vital interest to all students and graduates of the university because of the author's view of the role of the University in the national scene. It is all the more real because ... it recalls memories which are as much a part of the undergraduate career of every student as is Hart House."65

The Varsity Story had multifarious publication intents and thematic purposes. Upon its release, as an insider's story it was exuberantly received on the University of Toronto campus. Students lined up for hours at the university bookstore (see fig. 1) to purchase an autographed copy for twenty-five cents (see fig. 2). ${ }^{66}$ Attendees were offered the chance to speak to Callaghan as well as the book's illustrator, Eric Aldwinckle, who produced a number of recollective stylized woodcut illustrations to accompany the book. ${ }^{67}$ While Leacock bemoaned the moral quandaries and hypocritical self-deceptions involved in university fundraising, in contrast Callaghan's book was intended as a fundraiser for the University of Toronto which, in the aftermath of the war, had set an ambitious goal of $\$ 6$ million in gifts from alumni and friends. ${ }^{68}$ 


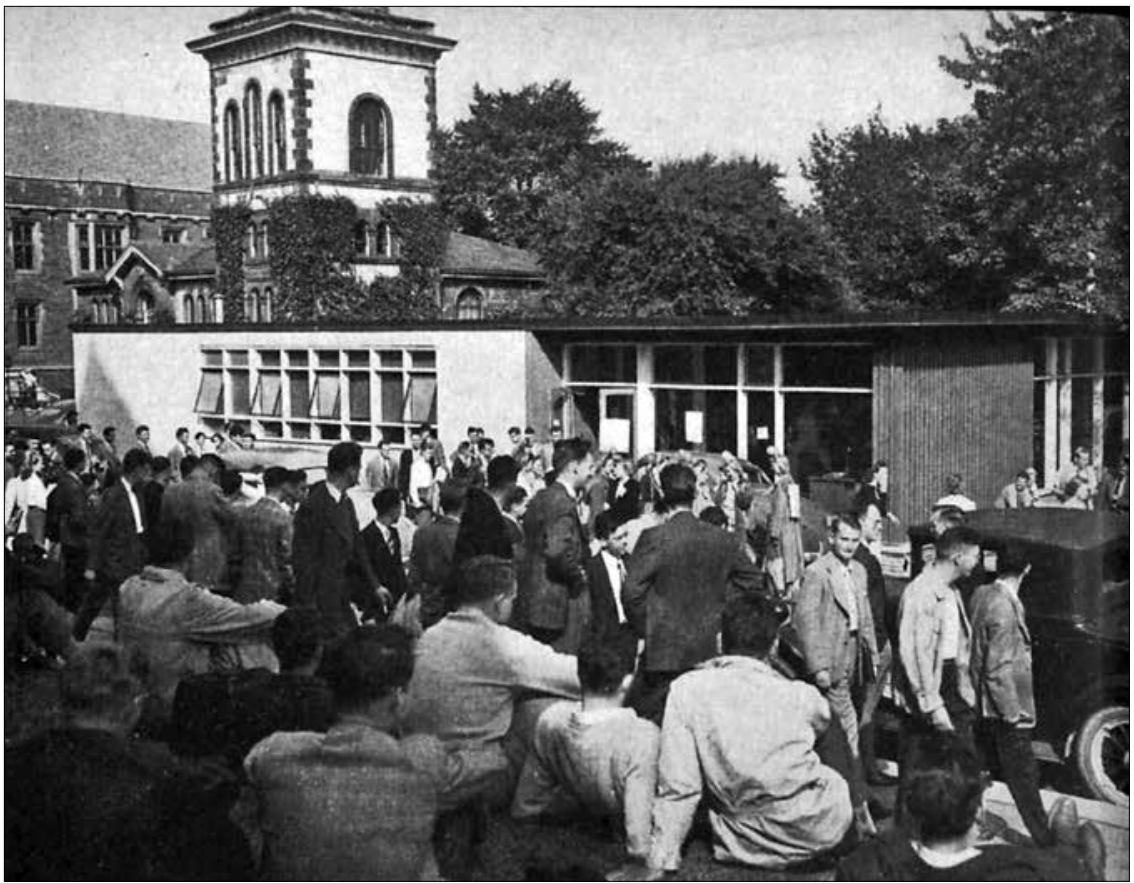

Figure 1: Crowd outside bookstore as The Varsity Story goes on sale. Varsity Graduate, Winter 1948, 18. Photograph courtesy of the University of Toronto Archives.

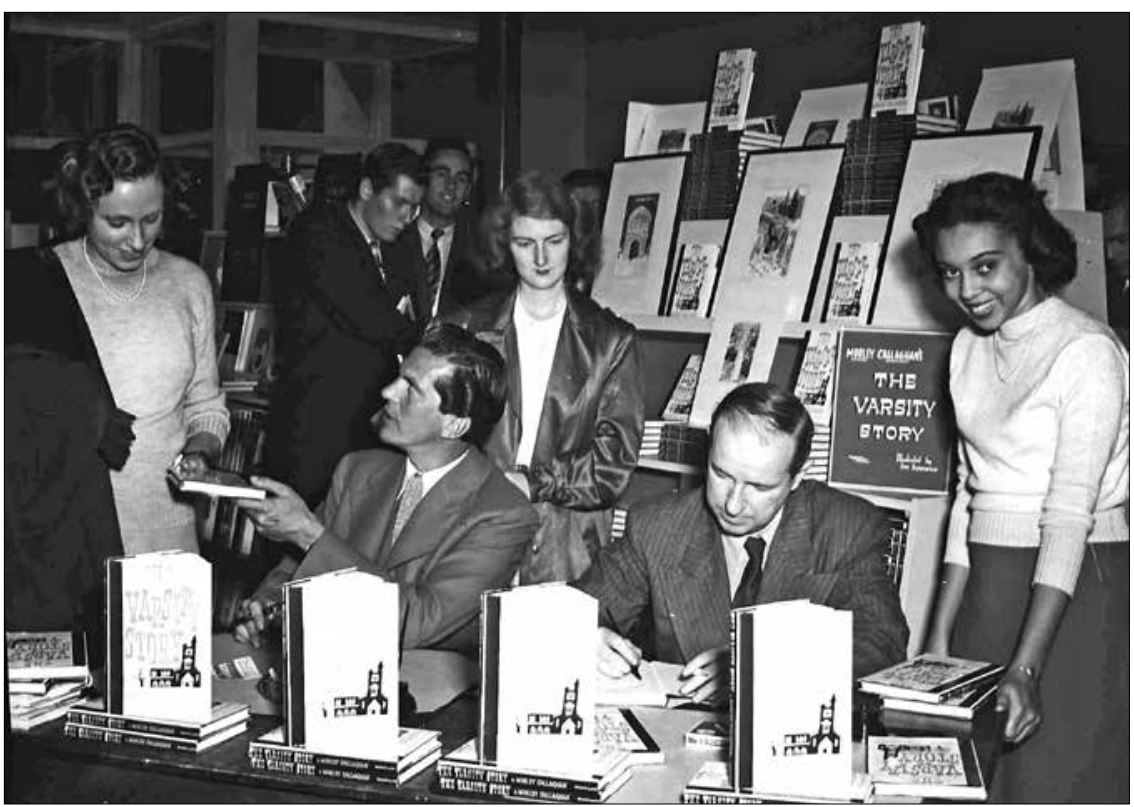

Figure 2: Eric Aldwinckle (left) and Morley Callaghan (right) autographing copies of The Varsity Story, 1948. WFM 034-1/B007. Photograph courtesy of the University of Toronto Archives. 
While Callaghan wrote the book to support the university's 1948 fundraising campaign and promote philanthropic investment in the university, ${ }^{69}$ he took the opportunity to ennoble the space of the campus as nurturing the intellectual and social lives of those who inhabited it. Callaghan dropped numerous hints to would-be philanthropist readers about the university's needs, such as a new men's residence and library as well as enhanced classroom spaces and scientific equipment. By February 1949, The Varsity Story had sold nearly 5,000 copies, an amount that must have surely pleased both Callaghan and university officials, with Callaghan donating his royalties to the university. ${ }^{70}$

In 1948, The Varsity Story was serialized in two parts on Canadian Broadcasting Company $(\mathrm{CBC})$ radio, galvanizing a critical discussion about the identity and character of campus life and, more widely, the place of higher education in the post-war world. Callaghan's adaptation - which also featured panel discussions by other notable students and professors from the University of Toronto - was prepared by Paul Fauteux, a third-year student at St. Michael's College at the university, and a radio commissioner for the Student Administrative Council (SAC). However, Fauteux was quoted as saying that: "It is not enough to have the program on a level of interest only to a university student but must have at least city-wide appeal." ${ }^{\prime 1}$

Callaghan tries to flesh out his characters' on-campus experiences through its campus space. One news source at the time claimed that Callaghan was trying to "psychoanalyze" the university. ${ }^{72}$ The book could be seen as a story of inquiry. In his review of the book, Deacon suggested that: "The Varsity Story is a book thrown out as an idea, of which we shall not hear the end for many a year." ${ }^{73}$ Callaghan uses his protagonists - Tyndall and Lane — to reveal the university's own complex ambience and "[distinct] way of life" that eschewed unnecessary old world referents. ${ }^{74}$ The campus spaces/places represented a mediated "living past." The paths on which students and professors walked and the outdoor areas on which students learned, socialized, and courted were critically seen as places of history and "good memories." "For the campus denizens, the memories imparted "particular intellectual and cultural ways," while enforcing other time-honoured university traditions and rituals such as varsity sports with attendant pomp and excitement.

Aldwinckle's black-and white stylized images that provocatively bookmark each of the thirteen chapters are a visual testament to the richness and sensuality of Callaghan's campus. His depictions of campus resonates from the detail of its features, including the size and complexity of the landscape that could swallow the individual visitor, as seen in an early anonymous photograph of the University of Toronto looking westward from Wellesley Street Gates (fig. 3). Figures 4-8 are lucid representations of the seasons on campus, with people, even at a varsity football game (fig. 4), dominated by the surroundings that were oft-times sprawling and mysterious (for example in fig. 5 and 6, the latter depicting campus figures dwarfed and tussled by a typical Canadian snowstorm). As viewers, we are asked to place ourselves seamlessly in the composition. The built and natural space wends in all directions through the larger university landscape (fig. 7). The Star suggested that Aldwinckle's illustrations were done in "a primitivism genre ... It is rather as if Granny Moses had left her 
New England farm landskips to catch the Varsity and Queen's Park buildings with bold gothic lines whose quirky perspectives are inspired by memory's fond but tricky eye rather than by the camera lens." ${ }^{.76}$
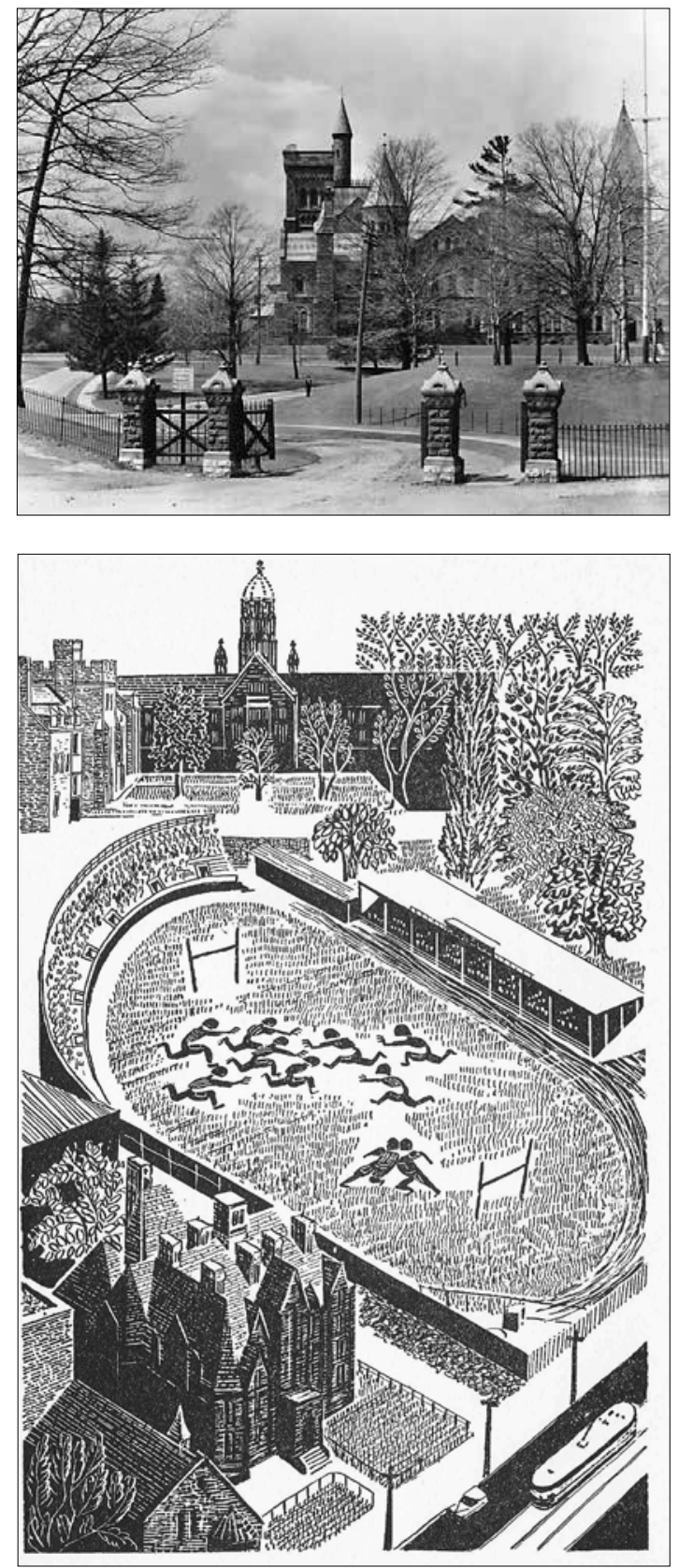

Figure 3: Wellesley Street Gates,

University of Toronto, 1907. E3-22r. Courtesy of Toronto Public Library.
Figure 4: Chapter 2, The Varsity Story, 22. 


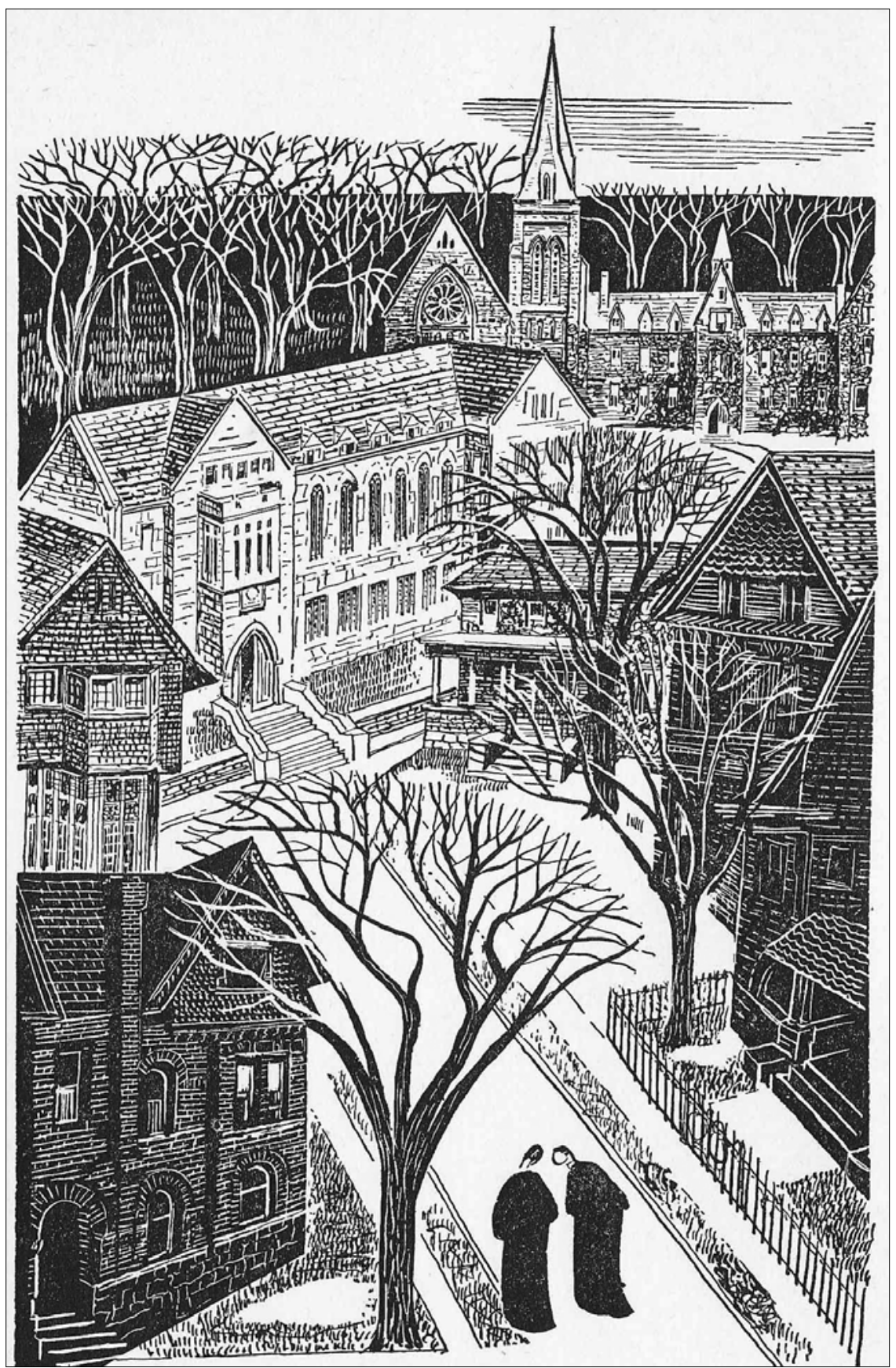

Figure 5: Chapter 12, The Varsity Story, 150. 


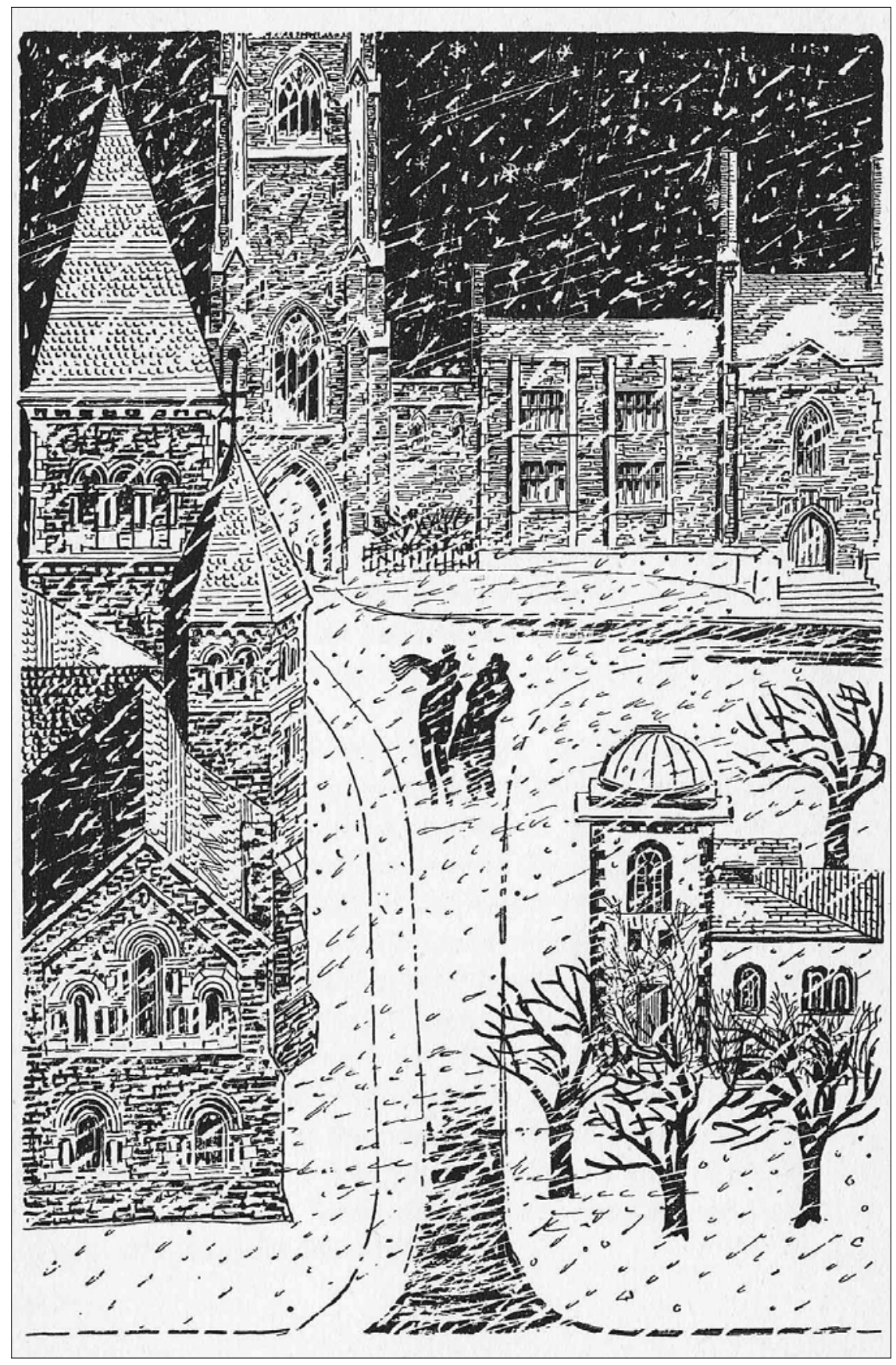

Figure 6: Chapter 7, The Varsity Story, 84. 


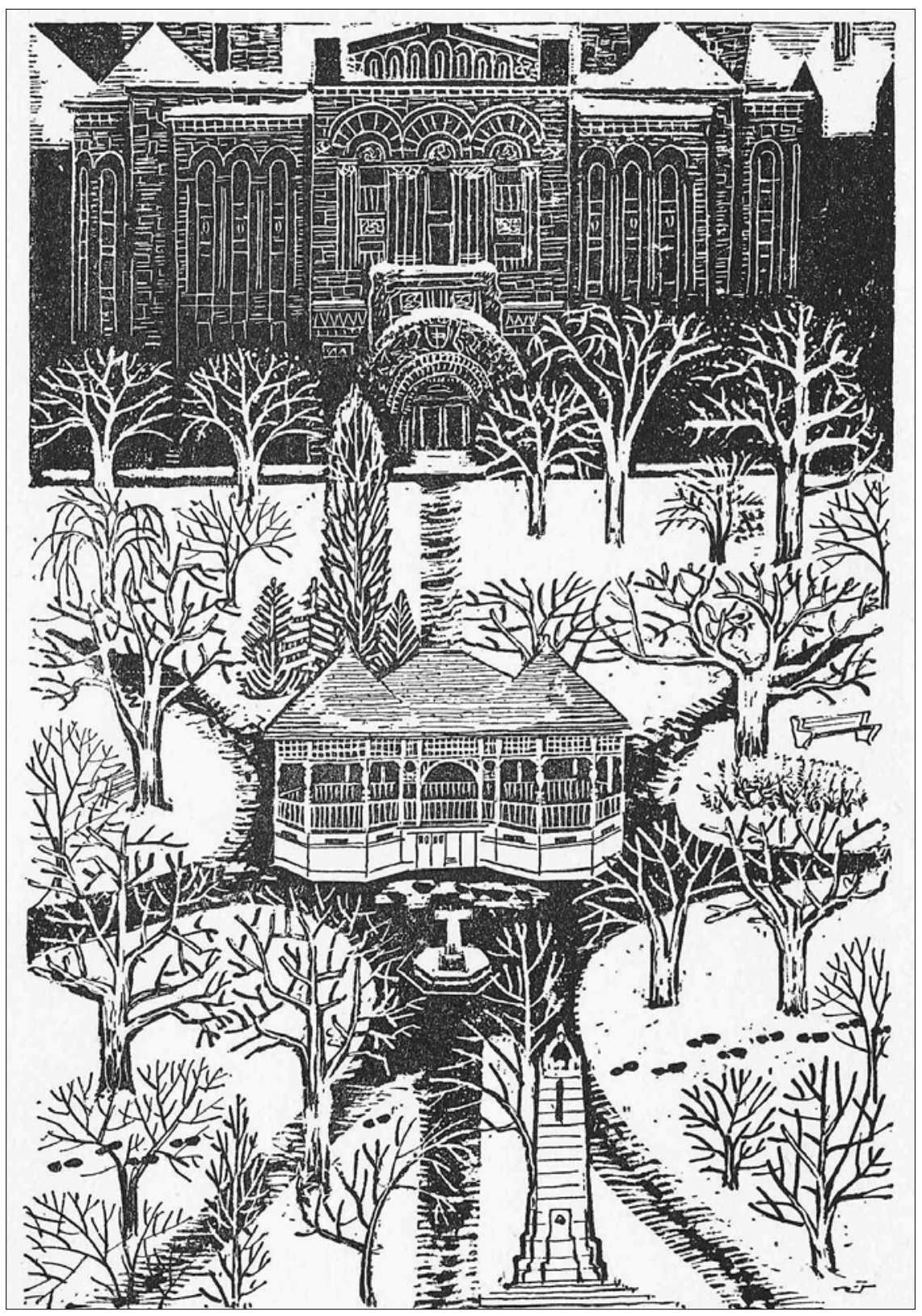

Figure 7: Chapter 5, The Varsity Story, 52.

Analogous to Leacock's campus tour, Callaghan relied on imagery associated with the contemplative act of walking and being a reflective agent and embodiment of the campus. Winding paths and rustic and natural landmarks provided students 
and professors with scholarly introspection and peripatetic encounters. Modeled on Aristotle's philosophy of walking and teaching, in the late nineteenth and twentieth century walking/strolling the campus was strongly identified with the educated thinking being. ${ }^{77}$ When not sequestered in his office or laboratory, the image of a meditative scholar (always represented as male) festooned in robes wandering through the byzantine cloisters became a popular representation of academic life. ${ }^{78}$ Such representations initially drew on the European image of the itinerant academic who travelled among medieval universities such as Bologna, Paris, Oxford, and Heidelberg. It was later reinforced by the nineteenth-century tradition of "walking," as promoted by naturalist writers such as William Wordsworth and Henry David Thoreau as well as Baudelaire's urbane elite male "flâneur," who walked the streets and avenues as a silent observer of city life. The practice of walking became a reflective act by campus inhabitants that cultivated ideas and formed the very basis of the value of intellectual space. ${ }^{79}$ More recently, images of "students strolling while conversing, riding bicycles, and lounging on the grassy knolls ... looks like Hollywood's quintessential portrayal of a college campus. ${ }^{80}$ Such performances both reflected and produced the campus and its cultural meanings and environs.

Enriching Aldwinckle's images, The Varsity Story waxes poetic: "[The] park and under the trees; ... the east wing of Trinity and up past the museum to Bloor Street $\ldots$ is a walk for lovers in spring at examination time." ${ }^{81}$ Generations of students, professors, and university staff "learned" how to traverse the historical campus to create intellectual, social, and cultural meanings around every corner. Walking these paths, one was confronted by the ghostly inheritances of knowledge and the great minds that had gone before. One's character was greatly influenced by the campus buildings for they "housed the ideas that made the whole of modern life what it was ... day-by-day the lives of millions of people in the country could be altered by what happened in those buildings." 82 One of the more striking images is the plate that introduces chapter 10 , which shows convocation, where the scope and detail of the stage replete with its massive pipe organ is as important as the proceedings below. The built environment engulfs the actors while working in harmony with them (fig. 8).

While Leacock focuses mostly on administrators, professors, and the institution as the subjective actors in a satirical academic culture and space, The Varsity Story makes an earnest effort to recreate the university's youth culture of the 1920s. Callaghan's own class of 1925 - at least the male members - was depicted as clever, bright, and aware of the social and occupational advantages of a university education. Leacock's and Callaghan's representations of women students as minor participants revealed each author's fixed understandings and broader cultural discourses about the role played by gender in higher education. As a reflection of the time, women students were often seen as ancillary to the culture and functioning of the university. In comparison to male students, as with Leacock, Callaghan tends to ignore the impact of women on campus, rendering their presence as marginal. Women students were literary ornaments: "Well dressed" and "fashionably ... pretty girls" were seen parading at football games and across the campus. "Girls in bright coats and dresses were like pigeons on the grass in that little corner between the tennis court and Burwash 


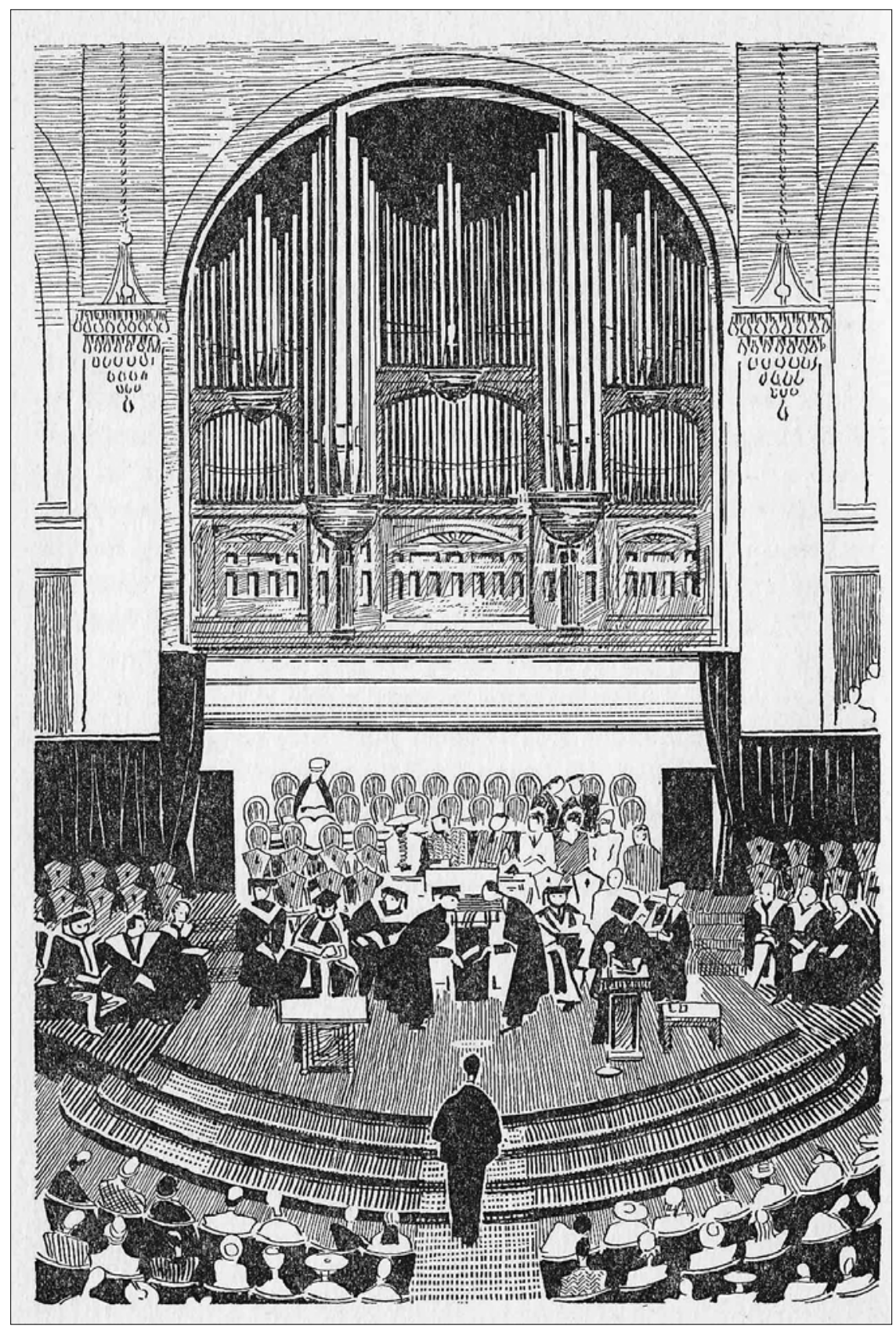

Figure 8: Chapter 10, The Varsity Story, 120. 
Hall." ${ }^{83}$ Helen Winston, student Tom Lane's girlfriend, is seen as a love interest rather than a budding intellectual in her own right. When Tyndall first meets her, she is described as the "tall dark-haired girl with the round face and dark eyes" who was "sitting on the grass with a good-looking blonde girl." Tyndall notes that Winston was "just a Victoria girl in a brown tweed overcoat and a fawn-coloured sweater." Throughout parts of the book, Winston seems to have a wandering eye for eligible men, commenting at one point that her hometown had "perhaps one eligible boy" where at Toronto "twenty boys [are] all in one lecture room." 85

The patronizing images of women students align with Callaghan's notion of gendered campus space. The campus novel has long been critiqued for being largely authored by men with patently patriarchal contemporary views and Leacock and Callaghan followed suit. Students were beholden to larger prevailing social values and expectations directed towards women. ${ }^{86}$ Yet at least one commentator saw Callaghan's few vivid depictions of women instead saying much. Discussing Callaghan's mention of women students in the book, the Varsity Graduate observed how "a girl student from Victoria swims in and out of the story: nothing happens: little is said: possibly 1500 words are devoted to her: but Callaghan, by sheer art, leaves in your mind a sense of comprehension and awareness of the co-eds of Varsity that had never taken form in either your mind or [in] your memory before." ${ }^{87}$

\section{The University Campus and Meanings of Space}

Depictions of life at the academy are located within the fictional or factual pulsating spaces of campuses. Unlike Leacock's President Boomer, who sought to ingratiate the university with the city's corporate and industrial sectors, Callaghan's University of Toronto is imagined as a separate entity, a more complex community that occupied its own place in what Toronto's "natives" called "the university neighbourhood" 88 (see fig. 9). While Plutoria's chief administrator misguidedly seeks a melding of the university space with the surrounding city — indeed, even a subsuming of the campus to outside interests - Callaghan's University of Toronto is rendered as an academic island that stands in sequestered, complacent contrast to the life and space of the rest of the city.

The intellectual heritage of Leacock's and Callaghan's campuses echoes the ideas of one of the leading social theorists in the nineteenth and twentieth centuries, John Ruskin (1819-1900) whose notion of environmental determinism was widely followed across the Anglo world. Adherents of Ruskin's theories included social and civic reformers, academics, artists, architects, professors, schoolteachers, and members of women's clubs. ${ }^{89}$ Environmental determinism was shaped by nineteenth-century English discussions of the degradation of society that resulted from urban industrialization and the loss of rural cultures and traditional landscapes. Ruskin argued that "beautiful" surroundings were the source of familial and human happiness and, by extension, the well-being of the nation-state and its social and educational institutions. His romantic socio-intellectual aesthetic discourse about experience and environment and one's place within them drove the consciousness of those who reflected 


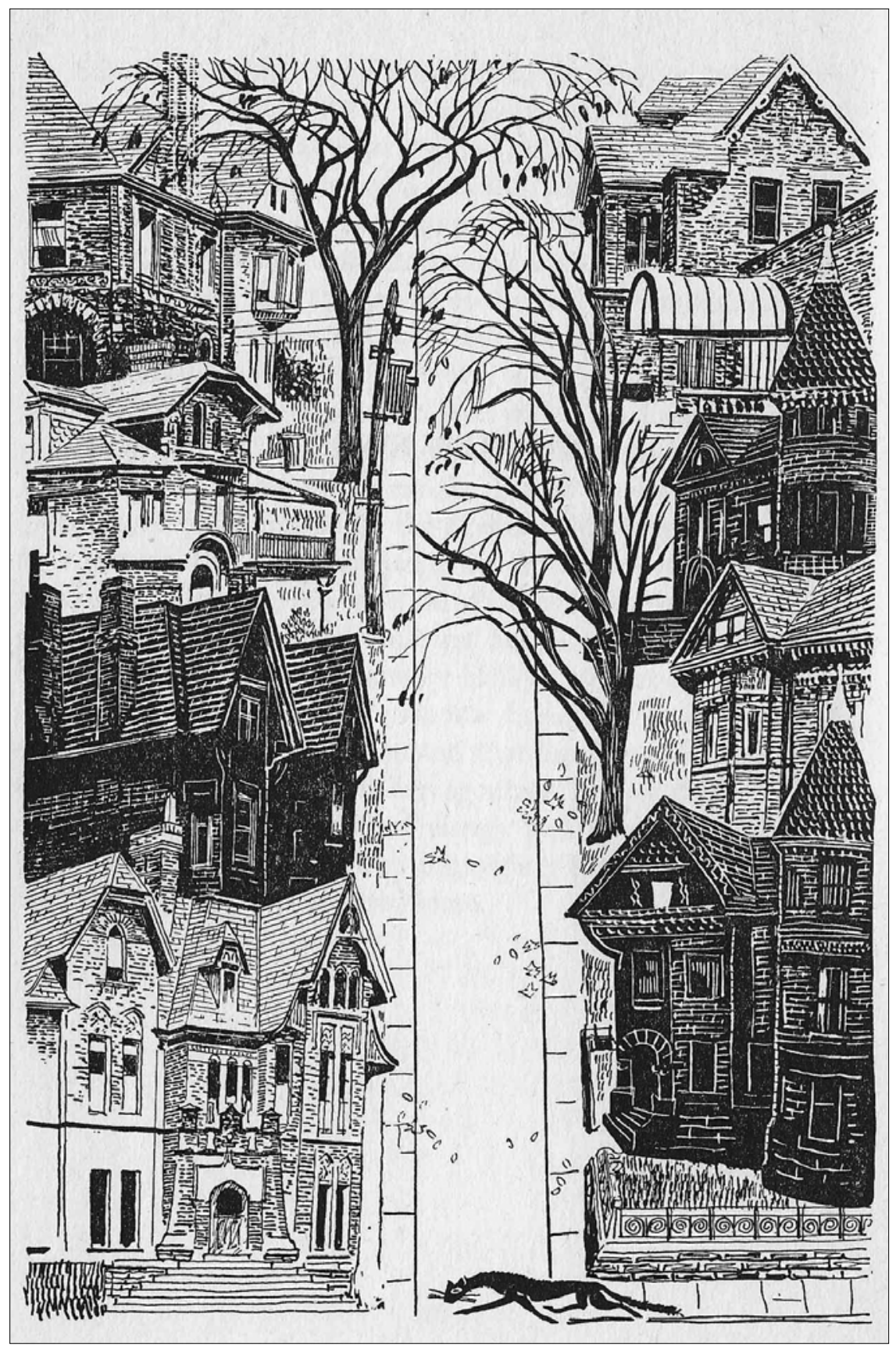

Figure 9: Chapter 9, The Varsity Story, 112. 
on and observed the campus. The relationship between the "good" and the "beautiful" became crucial to imagining the physical spaces of the university.

Ruskin's notion of "preserving natural beauty" is subtly invoked through Callaghan's description, as spoken through the narrator towards the beginning of the book, of coming upon campus and seeing "a little valley [in] what seems to be a village green, with the dome of the town hall outlined against the sky ... It looks like an old town. And it is too. It is a university town ... in the heart of the big industrial city." 90 Preserving this beauty in open spaces, which vitalized humane encounters, was integral to Ruskin's ideas about social relations. He symbolically charged exterior and interior environments with the metaphoric capacity to positively transform and democratize the individual maker and user as well as the surrounding community. ${ }^{91}$ The moral character of the environment was seen later with Leacock equating "bad" design with depravity and "good" design with virtue.

The moral and therapeutic effects of campus landscapes as understood through Ruskin's theories also gave rise to a distinctive notion of "Britishness" and nostalgia in Canada and other colonial countries, particularly through the academic lineage of Oxford, Cambridge, and Edinburgh. Reflecting the establishment of universities in England and Scotland in the nineteenth and early twentieth centuries, prior to 1950 English-Canadian university campuses were strongly influenced by and harkened back to the romantic landscape forms following British design. In 1944, for example, the Oxford Registrar and Regis Professor of Medicine visited President Henry John Cody and officials at the University of Toronto. His tour of the campus by Cody left him remarking that the campus, replete with its green space and Gothicrevival architecture, reminded him of some of the best parts of the Oxford grounds. ${ }^{92}$ Iconographic symbols such as the campus gates, a central village green, and lines of trees and open spaces that positioned aesthetic viewpoints became stock features for post-war universities seeking to mould a more expansive historical lineage and academic character. ${ }^{93}$

Arcadian Adventures and The Varsity Story invite questions about the spatial implications of the university typical of those that were founded centuries before in England and Scotland. The Ruskinian regard for medieval architecture and town planning was predicated on the assertion that spatial and built environments affected one's moral comportment and constitution while powerfully mediating attitudes, prejudices, expectations, and desires. In some of the British universities, the Gothic cloister was typically a small, college quadrangle of monastic construction enclosed from the outside with a small door on one side through which to enter. It forged the university as an intellectual island unto itself. Once inside, an expansive carpet of grass is bordered by small, stone walks. The outside community disappeared from view, accentuating the hallowed halls of reflective thought and contemplation. Andrew J. Feuer has noted that "The University of Toronto, while presenting an image of power and command to the city, incorporates spaces of contentment. These offer protection and a sense of belonging in the often intimidating environs." ${ }^{94}$ Leacock's proud albeit crumbling Concordia College and Plutoria's verdant campus represented an ideal long lost. To Leacock, however, the "ivory tower" - a term denoting the cold 
objectivity and separateness of the university from the society it is studying - seemed somewhere stuck in a liminal space between two highly discrepant worlds.

\section{Conclusion}

Through legend telling, the campus landscape transforms itself into a place that is strange and exciting, uncanny, and terrifying - not always comfortable but seldom dull. ${ }^{95}$

Universities in Canadian history have been historically dynamic and complex spaces that have evoked multiple layers of meanings and lived experiences as well as senses of individual and collective belonging or alienation. They have served as microcosms for larger social, economic, and political developments regionally and elsewhere. While historical agents conceptualized campus spaces through their own interpretive understandings based on personal and professional frameworks and varied cultural positioning and interests, Leacock and Callaghan were also intensely shaped by them. To both writers, the campus was their canvas. The imagined (Plutoria) or the real (University of Toronto) university was their outlet for commentary on how students, professors, and administrators negotiated their contingent daily working lives.

The books charted a distinctly Canadian genre of campus fiction. The campus was envisioned as a place that heralded the future while looking to a nostalgic past, an approach indicative of Canada in the early part of the twentieth century struggling with issues of increasing urbanization and the loss of the rural, the social upheaval caused by incendiary international geo-political developments and the First World War, and complex questions of identity that revolved around a Canadian colonial past and present. When Tyndall remarked that he only knew what a Toronto man was not, one cannot help but equate this with Canadian nationalism in the early to mid-twentieth century, and indeed later. Through their work, Leacock and Callaghan reflected mediated notions of social, intellectual, and cultural stagnation (Leacock) or a modernist sense of progress (Callaghan). Notably, these approaches that were directly related to Canadian identities, both regional and national, were still void of any lengthy or critical discussion of the implications of gendered, ethnic, or racial diversity or plurality on campus.

While the depictions of the academy's politics and life were invariably located within the spatiality of the campus, up until Leacock's and Callaghan's novels, and in much of higher education scholarship on socio-intellectual and academic lives even up to today, the campus has traditionally been the backdrop but rarely the extended or direct centre of attention. Using the juxtaposition of time, space, and the protagonist narrative, Leacock and Callaghan opened the campus itself to critical study: a romantic yet at times deeply capricious setting for university life. Leacock would argue that campus spaces were certainly less idyllic than the historic Arcadia as it was imagined by early Greek thinkers. They did, however, authorize identities and the operations of the institution as a site of idiosyncratically public, private, and academic performances that were deeply sardonic. Significantly, the idea of the "town 
and gown" - the perceived and actual social and cultural separation of the university from its surrounding community - was crafted in these discursive and visual accounts. A major difference between Leacock's and Callaghan's depictions of the town and gown is that Leacock saw the city and its stoic and utilitarian cultures and prosaic office towers of accountability and corporate and industrial agendas encroaching on university space. In contrast, Callaghan saw more of a resplendent landscape that was at peace with its intellectual and cultural sovereignty. In this way, Leacock's university was cynical and threatened; Callaghan's was optimistic and tranquil.

The campus was embodied and metaphorically produced in Leacock's President Boomer, Tomlinson, and Boyster, and Callaghan's Tyndall and Lane. The subjectivities of the characters become allegory: their motivations and dialogue connote stories and lessons extracted from incidents that centred on university politics, academic and personal interrelationships, and intellectualism within the fluid spatial dimension of the campus. Both authors acquainted themselves and their readers with the university through the "campus tour" or the intellectual peregrinations along the philosopher walks of richly lined paths and imposing built structures. The authors challenged the readers to empathetically envisage academic lived experiences in partnership with the unique and resonant complex aesthetic of the campus.

To both Leacock and Callaghan, the campus is living and breathing. Their use of cultural symbolism of the campus raises important historiographical and methodological debates about the construction of identities and subjectivities. Northrop Frye once noted that "Canadian sensibility has been profoundly disturbed, not so much by our famous problem of identity, important as that is, as by a series of paradoxes in what confronts that identity. It is less perplexed by the question 'Who am I?' than by some such riddle as 'where is here?' " 96 Critically updating this question, we see how campus environments affected one's socio-cultural and educational meaning-making within profoundly transformative intellectual historical space and place.

\section{Notes}

1 We wish to thank Margaret Bridgman for permission to reproduce Eric Aldwinckle's illustrations from The Varsity Story. We also thank Ken Puley from CBC Radio Archives, Simon Bailey, Keeper of the Archives at the Bodleian Library, University of Oxford Archives, and Harold Averill and Marnee Gamble at the University of Toronto Archives. This research is funded through a Social Sciences and Humanities Research Council of Canada Insight Grant.

2 Student campus papers, such as University of Toronto's The Varsity and McGill's The Daily, were long replete with affectionate homages to campus gargoyles. See Terry Murray, Faces on Places: A Grotesque Tour of Toronto (Toronto: House of Anansi Press, 2006).

3 A 1998 architectural and landscape study at the University of Virginia's 1825 Jeffersonian-designed campus noted that: "People often don't think of landscapes as being historic in any way, especially on a college campus ... [b] ut the universities iconic core is the Lawn." Paul Bennett, "It Takes a Village: Drawing on the Legacy of Jefferson, Campus Planners at the University of Virginia Plot a Future Based on the Past," Landscape Architecture 88, no. 10 (1998): 74, 7681. 
4 Edward Relph, Place and Placelessness (London: Pion Limited, 1976), preface.

5 Grady Clay, Close Up: How to Read the American City (Chicago: University of Chicago Press, 1973), 13.

6 Janice Rossen, The University in Modern Fiction: When Power Is Academic (London: The McMillan Press, 1993), 1.

7 "Fictional-factual" is helpful in understanding the interplay between the real and the imagined in these authors' works. For a discussion of the concept, see Lennard J. Davis, Factual Fictions: The Origins of the English Novel (Philadelphia: University of Pennsylvania Press, 1996).

8 Constance Beresford-Howe, Of This Day's Journey (New York: Dodd, Mead \& Co, 1947). On Régis Messac, Smith Conundrum: Roman d'une université américaine (Paris: Editions ex nihilo, 1942), see Marc Angenot, Régis Messac, Smith Conundrum. Roman d'une université américaine (2010), and Marc Angenot, "Un roman satirique sur McGill University," Voix et Images 3, no. 1 (1977): 162-165.

9 Elaine Showalter, Faculty Tower: The Academic Novel and its Discontents (Philadelphia: University of Pennsylvania Press, 2009), 1.

10 McGill University has been the subject of many literary and artistic expressions. For example, see Robert H. Michel, "Floreat Plutoria: Satirical Fiction About McGill," Fontanus IX (1996): 29-45.

11 Allen G. Noble and Ramesh Dhussa, "Image and Substance: A Review of Literary Geography,” Journal of Cultural Geography 10 (1990): 49.

12 Amy Lavender Harris, Imagining Toronto (Toronto: Mansfield Press, 2010), 295.

13 Thomas Bender, ed., The University and the City: From Medieval Origins to the Present (Oxford: Oxford University Press, 1988), 5. Instructive interdisciplinary methodological discussions and debates in literary geography are found in, for example, Brian Osborne, "Some Thoughts on Landscape: Is it a Noun, a Metaphor, or a Verb?" Canadian Social Studies 32, no. 3 (Spring 1998): 93-98; Sara Blair, "Cultural Geography and the Place of the Literary," American Literary History, 19, no. 3 (Fall 1998): 544-567; and Noble and Dhussa, "Image and Substance," 49-65.

14 A sample of these interdisciplinary literatures offers both internal and external perspectives. Blake Gumprecht's, The American College Town (Amherst: University of Massachusetts, 2008), illustrates the way in which college towns and campus spaces arose in the United States relative to economics and educational ideologies. Herman van der Wuste, The Urban University and Its Identity (Dordecht, Netherlands: Kluwer Academic Publishing, 1998), and Bender, The University and the City, provide important ways to think about the often conflict-ridden relationship between the city and campus. See also Paul Venable Turner, Campus: An American Planning (New York: MIT Press, 1984); Richard Dober, Campus Design (New York: John Wiley, 1992); and Thomas A. Gains, The Campus as a Work of Art (Westport, Connecticut: Praeger, 1991) that focus on the architectural planning of the American campus since the seventeenth century.

15 The terms "campus" or "college" fiction is used in the United States and Canada, while in Britain "academic fiction" and "university fiction" are more popular terms.

16 The varsity/college novel on the lives of students further delineates the broader genre of campus fiction. Notably, John McNally's edited collection, The Student Body: Short Stories about College Students and Professors (Madison, Wisconsin: University of Wisconsin Press, 2001), brings together an eclectic collection of authors such as Richard Russo and Stephen King who, in their short stories, have explored campus life and relations between professors and their students. See Mark C. Embersole, ed., Hail to Thee, Okobojiu! A Humor Anthology on Higher Education (New York: Fordham University Press, 1998). 
17 Peter Nover, ed., The Great Good Place: A Collection of Essays on American and British College Mystery Novels (New York: Peter Lang, 1990).

18 C. P. Snow, The Masters (New York: Scribner's, 1951); Mary McCarthy, Groves of Academe (New York: Harcourt, Brace, 1952); Kinsley Amis, Lucky Jim (New York: Penguin Classics, 1954). Amis's Lucky Jim is regarded by Kenneth Womack as "the quintessential campus novel of the twentieth century." Postwar Academic Fiction (New York: Palgrave, 2002), 27.

19 Rossen, The University in Modern Fiction, 2. For further analyses of the genre of academic and university fiction, see Mark Bosco and Kimberly Connor Rae, eds., Academic Novels as Satire: Critical Studies of an Emerging Genre (New York: The Edwin Mellen Press, 2007); Bruce Robbins, "What the Porter Saw: On the Academic Novel," in A Concise Companion to Contemporary British Fiction, ed. James E. English (Oxford: Blackwell Publishing, 2006), 248-266; Kenneth Womack, "Academic Satire: The Campus Novel in Context," in A Companion to the British and Irish Novel 1945-2000, ed. Brian W. Shaffer (Oxford: Blackwell Publishing, 2005), 326-339; John E. Kramer, Ron Hamm, and Von Pittman, eds., The American College Novel: An Annotated Bibliography, second edition (Lanham, Maryland: Scarecrow Press, 2004); David Bevan, University Fiction (Atlanta: Rodopi, 1990); Rossen, The University in Modern Fiction; Showalter, Faculty Towers, and Ian Carter, Ancient Cultures of Conceit: British University Fiction in the Post War Years (London: Routledge, 1990).

20 Showalter, Faculty Towers, 2.

21 Rossen, The University in Modern Fiction, 3.

22 Mortimer R. Proctor, The English University Novel (Berkeley: University of California Press, 1957), 185. For discussion and examples of the "Oxford novel" see Judy G. Batson, Oxford in Fiction: An Annotated Bibliography (New York: Garland Publishing, 1989).

23 Gerald Lynch, ed., Leacock on Life (Toronto: University of Toronto Press, 2002), xv. A biographical anthology of Leacock was produced as early as 1923: see Peter McArthur, Stephen Leacock Biography: Critical Appreciation and Anthology (Toronto: Ryerson Press, 1923). Key biographical works on Leacock include: Margaret MacMillan, Stephen Leacock (Toronto: Penguin Canada, 2009); David Staines, The Letters of Stephen Leacock (Don Mills, Ontario: Oxford University Press, 2006); and David Staines, ed., Stephen Leacock: A Reappraisal (Ottawa: University of Ottawa Press, 1986); Gerald Lynch, Stephen Leacock: Humour and Humanity (Kingston, Ontario: Queen's University Press, 1988); David Legate, Stephen Leacock: A Biography (Toronto: Macmillan, 1978); Alan Bowker, The Social Criticism of Stephen Leacock (Toronto: University of Toronto Press, 1973); Ramsay Cook, "Stephen Leacock and the Age of Plutocracy, 1902-1921," in Character and Circumstances: Essays in Honour of Donald Grant Creighton, ed. John S. Moir (Toronto: Macmillan, 1970), 163-181.

24 By the time he wrote Arcadian Adventures, among other pieces Leacock had already published an academic textbook on political science, two books of humour, and an economic history: Baldwin, Lafontaine, Hincks: Responsible Government (Toronto: Morang \& Co., Limited, 1907).

25 Myron J. Frankman, "Stephen Leacock, Economist: An Owl Among the Parrots" in Stephen Leacock: A Reappraisal, ed. David Staines (Ottawa: University of Ottawa Press, 1986), 51-58, discusses Leacock's scholarly reception as an economist. James Doyle has noted that Leacock's Arcadian Adventures, "was part of the popular form of anticapitalist fiction produced in the early twentieth century." James Doyle, Progressive Heritage: The Evolution of a Politically Radical Literary Tradition in Canada (Waterloo: Wilfrid Laurier Press, 2002), 51. 
27 Michel, "Floreat Plutoria," 30. Edgar Andrew Collard's, The McGill You Knew: An Anthology of Memories, 1920-1960 (Don Mills, Ontario: Longman Canada, 1975), has a whole chapter dedicated to "Leacock Memories." See Ian Ross Robertson, "Sir Andrew Macphail and the Pen and Pencil Club of Montreal," in Thinkers and Dreamers: Historical Essays in Honour of Carl Berger, ed. Gerald Friesen and Doug Owram (Toronto: University of Toronto Press, 2011), 126-143.

28 Leacock, Arcadian Adventures, 53.

29 Ibid., 52. 'Nothing concerning humanity is alien to me." Leacock's critique of academic pretention is situated in Boomer's frequent use of Latin. Françoise Waquet has noted that to Leacock, Latin was intended "to bulldoze resistance ... [and] to hijack the consent of others." To build the campus of the future, Latin was used as a "strategy with businessmen" to remind them of the exclusive and privileged heritage of the institution that they had access to only through a generous donation to the university. Françoise Waquet, Latin, or the Empire of the Sign, translated by John Howe (London: Verso, 2001), 238.

30 Leacock, Arcadian Adventures, 53.

31 For example, see discussions about symbolic landscape and its relation to religious and educational contexts in Denis Cosgrove and Stephen Daniels, eds. The Iconography of Landscape (Cambridge: Cambridge University Press, 1988), and Rod Barnett, "Sacred Groves: Sacrifice and the Order of Nature in Ancient Greek Landscapes," Landscape Journal 26, no. 2 (2007): 252-269.

32 Leacock, Arcadian Adventures, 54, 57-58.

33 MacMillan, Stephen Leacock, 95. Some of Leacock's serious and satirical campus fiction include: College Days (Toronto: S. B. Gundy, 1923); "Looking Back on College" (97-100), "Paradise Lost" (209-211), and "On the Need for a Quiet College" (101-106), in On the Front Line of Life: Stephen Leacock Memories and Reflections, 1935-1944, ed. Alan Bowker (Toronto: Dundurn Group, 2004); Too Much College, or Education Eating Up Life: With Kindred Essays in Education and Humour (New York: Dodd, Mead and Company, 1939); "The Apology of a Professor: An Essay on Modern Learning," in The Social Criticism of Stephen Leacock, ed. Alan Bowker (Toronto: University of Toronto Press, 1973), 28-50. Leacock's “A Sermon on Humour," The Goblin 1, no. 1 (1921): 9-10 was subsequently published in the British/American edition of College Days (1923).

34 Leacock, Arcadian Adventures, 55.

35 Vishnu R. Chopra. "From Manuscript to Print. Stephen Leacock's 'The Transit of Venus'." Canadian Literature 121 (1989): 42-53.

36 Leacock, Arcadian Adventures, 56-57.

37 Bowker, On the Front Line of Life; Elizabeth Kimball, The Man in the Panama Hat: Reminiscences of my Uncle, Stephen Leacock (Toronto: McClelland \& Stewart, 1970).

38 Leacock, Arcadian Adventures, 64.

39 As cited in Bowker, On the Front Line of Life, 106. As Chopra has discussed, Leacock's "Transit of Venus" was a serious and sentimental story about an older professor marrying a young woman student.

40 Leacock, Arcadian Adventures, 55.

41 Ibid., 63.

42 Bowker, On the Front Line of Life, 15,17.

43 Ibid., 97.

44 Ibid., 101.

45 Leacock, Arcadian Adventures, 75.

46 Leacock's name of the professor "Gildas" may have been in reference to the historian Gildas, whose background is historically ultimately unclear. He is thought to have been a monk who lived in the sixth century (exact dates unknown). He wrote about 
fifth- and sixth-century Britain, possibly to "persuade and cajole," and has been accorded "a significant place ... in the monastic history of both Britain and Brittany" (Gabriele Marasco, ed., Greek and Roman Historiography in Late Antiquity: Fourth to Sixth Century, A. D. [Brill: Leiden, 2003], 376, 378). In his writings, Gildas includes "a long series of scriptural extracts designed to illustrate ... his invective about the corruption of [Britain's] rulers ... and clergy ... and to provoke his audience to repent." His major work is designed to denounce rulers in society and the church "with all their transgressions itemized ... God has allowed the Saxon domination [over the Britons] ... because of the despicable behaviour of the kings and their officials" (379). One cannot help but make this allegorical connection to Leacock's Gildas, who exposes the charade of fool's gold in the context of the university that has become morally uncertain.

47 Callaghan's friendships with numerous authors such as Ernest Hemingway, with whom he worked as a newspaper reporter at the Toronto Star Weekly in the 1920s, and F. Scott Fitzgerald, James Joyce, and Ezra Pound are discussed in his 1963 memoir, That Summer in Paris (Holstein, Ontario: Exile Press, 1963).

48 “Toronto Fictionalist Joins Celebrities: Morley Callaghan Has Jolted Authors' World by Selling Canadian Stories to Difficult U.S. Market." Star Weekly (March 17, 1928). University of Toronto Archives (UTA), Department of Graduate Records, A73-0026.

49 Margaret Lawrence, "Morley Callaghan," Saturday Night, July 14, 1928.

50 Tyndall might have been fashioned after J. R. Bickersteth, the first warden of Hart House, who arrived in 1921 and remained at the university until his retirement in 1947. "Bickersteth, John Burgon," UTA, B2005-0013 and B2001-0018. Hart House was founded by Vincent Massey on behalf of his family's philanthropic trust, the Massey Foundation, and opened in 1919. It was intended to recreate the rich and vibrant student life Massey had experienced as an undergraduate at Balliol College, Oxford. For Callaghan's class of '25, and for him as an active alumnus in 1948, Hart House was seen as the locus of social and cultural life on campus for male students and professors. On Hart House, see: David Kilgour, ed., A Strange Elation: Hart House, the First Eighty Years (Toronto: University of Toronto Press, 1999); Ian Montagnes, An Uncommon Fellowship: The Story of Hart House (Toronto: University of Toronto Press, 1969); E. Lisa Panayotidis and Paul Stortz, "The Mythic Campus and the Professorial Life: A. Scott Carter's Pictorial Map of the University of Toronto, 1937," History of Education Review 40, 1 (2011): 9-29.

51 Callaghan, The Varsity Story, 17.

52 Ibid., 18.

53 Ibid., 11.

54 As part of a series of articles on the leading universities in Canada and the United States, Callaghan mocked varsity for its elite as well as feminized rituals. "Callaghan Finds Tea Varsity's Pet Habit," Toronto Mail, January 8, 1930.

55 Callaghan, The Varsity Story, 54-55.

56 Larry McDonald, "The Civilized Ego and its Discontents: A New Approach to Callaghan," in The Callaghan Symposium, ed. David Staines (Ottawa: University of Ottawa Press, 1981), 79.

57 Callaghan, The Varsity Story, 57.

58 Ibid., 162.

59 Ibid., 168.

60 See McDonald, "The Civilized Ego and its Discontents"; Patricia Morley, "Morley Callaghan: Magician and Illusionist," in The Callaghan Symposium, ed. David Staines (Ottawa: University of Ottawa Press, 1981), 59-60; "The Novel Approach,” Time Magazine, February 7, 1949: 7.

61 William Arthur Deacon, "Is the University of Toronto a Machine or Living Entity?" Globe and Mail, October 23, 1948. 
62 Northrop Frye, "Review of The Varsity Story," Canadian Forum XXVIII, no. 334 (November 1948): 189.

63 Varsity Graduate (December 1948): 19.

64 Gregory Clark, “The Varsity Story," Varsity Graduate (December 1948): 19, 22.

65 "Canadian Author at Press to Autograph Novel Today," The Varsity LXVIII, no. 6 (September 30, 1948): 1.

66 Ibid.

67 Eric Aldwinckle (1909-1980) was born in Oxford, England. He arrived in Canada in 1922 where he apprenticed in graphic design. He launched a successful career in the 1930s doing design work for a variety of institutional university and business clients. During the 1940s, he was appointed a war artist and sent overseas. A life-long member of the Toronto Arts and Letters Club, he taught part-time at the Ontario College of Art and his art was a regular feature at Hart House at the University of Toronto.

68 "The Novel Approach," 3.

69 No evidence exists regarding how Callaghan was approached to write the book for the university, nor that he made a direct profit from the sales of the book.

70 "The Novel Approach," 3.

71 The Varsity Story was presented in two installments and aired on November 11 and 18, 1948 on CBC Radio. "Callaghan's Varsity Story Will be Presented on Air," The Varsity (October 9, 1949): n.p.

72 "Varsity Psychoanalyzed by Novelist Callaghan," Star, September 25, 1948: 7.

73 Deacon, "Is the University of Toronto a Machine or Living Entity?"

74 Callaghan, The Varsity Story, 3.

75 Ibid., 27.

76 "Varsity Novel Psychoanalyzed by Callaghan," Star, 7.

77 Felix Grayeff, Aristotle and his School: An Inquiry into the History of Peripatos (London: Gerald Duckworth, 1974).

78 Daniel Wilson, the University of Toronto's third president, had a particular fondness for walking the campus alone or in the company of students. See Elizabeth Hulse, ed. Thinking with Both Hands: Sir Daniel Wilson in the Old World and the New (Toronto: University of Toronto Press, 1999).

79 On the Anglophone peripatetic tradition and the relationship between walking and thinking, particularly among post-Enlightenment philosophers, poets, and historians, see Anne D. Wallace, Walking, Literature, and English Culture (Oxford: Oxford University Press, 1993), and Rebecca Solnit, Wanderlust: A History of Walking (New York: Penguin Books, 2000).

80 Peter M. Mogalda, "The Campus Tour: Ritual Community in Higher Education," Anthropology \& Education Quarterly 31, no. 1 (March 2000): 27.

81 Callaghan, The Varsity Story, 3. Presaging Tyndall's aesthetic/intellectual "turn," this quote appears early in the book.

82 Ibid., 13.

83 Ibid., 34.

84 Ibid., 40-41.

85 Ibid., 47.

86 These social and cultural constraints faced by women students, academics, and administrators were widespread historically and geographically. See E. Lisa Panayotidis and Paul Stortz, eds., Women in Higher Education, 1850-1970: International Perspectives (New York: Routledge, 2016). For an international analysis of campus fiction as it applies to women, for example, see: Ann McClellan, How British Women Writers Transformed the Campus Novel (Lewiston, New York: The Edwin Mellen Press, 2012); "University Women in Frances Marshall's Fiction," English Literature in Transition, 1880-1920 52 (2010): 331-49; Gunilla Lindgren, Higher Education for Girls in North 
America College Fiction, 1886-1912 (Lund: Lund University Press, 2005); Sherrie A. Inness, Intimate Connections: Representation and Social Transformation in Women's College Fiction, 1895-1910 (Bowling Green, Ohio: Bowling Green State University Popular Press, 1995); Shirley Marchalonis, College Girls: A Century in Fiction (New Brunswick, New Jersey: Rutgers University Press, 1995); and Susan J. Leonardi, Dangerous by Degrees: Women at Oxford and the Somerville College Novelists (New Brunswick, New Jersey: Rutgers University Press, 1989).

87 The Varsity Graduate, 22.

88 Callaghan, The Varsity Story, 2. For a historical account of the University of Toronto as an integral part of the broader Annex neighbourhood, see Jack Batten, The Annex: The Story of a Toronto Neighbourhood (Erin, Ontario: Boston Mills Press, 2004).

89 E. Lisa Panayotidis, "James Mavor: Cultural Ambassador and Aesthetic Educator to Toronto's Elite, 1892-1925," Journal of Pre-Raphaelite Studies 6, 7 (1997-98): 161-173; and "Artist, Poet, and Socialist': Academic Deliberations on William Morris at the University of Toronto, 1896-1925," Journal of William Morris Studies 12, 4 (1998): 36-43.

90 Callaghan, The Varsity Story, 2.

91 John Ruskin, The Works of John Ruskin, in E. T. Cook and Alexander Wedderburn, eds., (London: George Allen, 1903-12).

92 Oxford University Archives, Registry File Regarding Medieval Schools, UR6/ $\mathrm{MD} / 13 / \mathrm{B} / 1$, October 1944. On the relationship between the English landscape tradition and discourses of nation in the Anglo-world see, for example David Matless, Landscape and Englishness (London: Reaktion Books, 2005).

93 See Diane Cornell, “ 'The New Urbanism': How John Ruskin's Ideas Influenced Generations of Urban Planners," Rutger's Focus, February 4, 2000.

94 Andrew J. Feuer, "University of Toronto. A Phenomenological Understanding" (A fifth year research and development project, School of Architecture, Carleton University, 1984), 6.

95 Elizabeth Tucker, Campus Legends: A Handbook (Westport, Connecticut: Greenwood Press, 2005), 14.

96 Northrop Frye, The Bush Garden: Essays on the Canadian Imagination (Toronto: Anansi Press, 1971), 222. 